\title{
Effect of crude oil pollution on organic carbon and humus content in grey-brown soils in Mangyshlak, Pre-Caspian Sea Region
}

\author{
Saimbulek DOSBERGENOV* \\ U.U. Uspanov's Kazakh Scientific-Research Institute of Soil Science and Agricultural Chemistry, Almaty 050060, Kazakhstan
}

\begin{abstract}
The organic carbon and humus content in oil polluted brown and grey-brown soils in Mangyshlak, Pre-Caspian Sea Region, was analyzed from 2000 to 2008. The results indicated that bitumen substances from crude oil pollution deteriorated the soil property, however, the organic carbon content increased significantly. The products of oil pollution changed the composition of carbonaceous substances which formed soil humus, and changed the ratios of the humus components. Residual insoluble carbon increased with the rise of oil organic carbon. The mobility of humus components was significantly increased because of the high oxidation-reduction process in the topsoil, and the humus content and microorganism activity increased. The organic carbon content increased significantly, while it decreased with the distance away from the oil well. The rearrangement of physical, physical-chemical and chemical properties of the polluted soils was significant.
\end{abstract}

Keywords: oil-chemical pollution; humus; transformation; degradation; Pre-Caspian Sea Region

\section{Introduction}

Oil-chemical pollution of soil is a central environmental issue in the Caspian Sea Region due to oil and gas exploitation. Irrational use of raw material resources, a progressive increase in anthropogenic influence on the soil, and frequent oil-spills resulted in the formation of oil 'pits' and 'polygons' in the ecologically destabilized territories. The geochemical condition, carbon-nitrogen balance and element composition of the soil may be significantly modified by severe oil pollution.

Oil pollution caused by oil industry wastes, leaching from equipment and spills has led to $5 \times 10^{5} \mathrm{hm}^{2}$ salinization soil and the degradation of ecosystems (Saparov et al., 2006). In the oil-polluted soils, the important genetic indices created by nature over thousands of years are altered, including change of humus content and composition, formation of bitumen crusts, disturbance of soil-absorbing complexes, and decreases in porosity, aeration, water-air properties and ecological stability. Toxic chemicals accumulate in the soil and have caused many human diseases, such as hepatitis, lung diseases, tuberculosis and cancers. The increase of 'professional diseases' among local people and the loss of cattle have been related to these toxic chemicals (Bigaliyev et al., 2002). Oil exploitation, refining, sewage treatment and tankers increase the pollution of the Pre-Caspian Sea. Pollution by crude oil, which contains $20 \%-25 \%$ hydrogen sulfide, caused the deaths of water birds, migratory birds and mammals. The death of these animals had a negative effect on the bio-productivity of the Caspian Sea (Dusenov, 2001).

The oil pollution problems of Kazakhstan have not been solved and require further comprehensive study. Decontamination of the environment in the oil-industry regions of Kazakhstan is an urgent task for the government. It is necessity to detect centralized oil-polluted regions, the regularity of their geochemical migration, the composition and toxicity of the pollutant. The aim of the present study is to clarify the effect of oil pollution on organic carbon content, humus content and composition in the grey-brown soil.

Received 2009-11-06, accepted 2010-04-16

doi: $10.3724 /$ SP.J.1227.2010.00133

*Corresponding author: Saimbulek DOSBERGENOV (E-mail: saparov@nursat.kz) 


\section{Materials and methods}

The research was carried out on the monitoring sites of Zhanaozen oil-field (grey-brown soils) and Dossor oil-field (brown soils) in the Pre-Caspian Sea Region. Both sites were polluted by crude oil and oil industry wastes from 2000 to 2008 . The soil was saline, being composed of loam, sandy-loam, sands and clay. Twenty-eight monitoring holes were drilled in the affected soils by oil wells representing a total area of $10,000 \mathrm{~m}^{2}$.

The soil profiles were drawn, and the soil samples were selected according to the soil horizons (Ponamareva et al., 1975). The group and fractional composition of humus, total content of organic carbon and humus were measured using Turin methods (Turin, 1937). The comparative-ecological analyses of soils were undertaken according to common methods in soil science (Arinushkina, 1961).

\section{Results and discussion}

\subsection{Organic carbon and salt contents in the oil-polluted soil}

The results of the research indicated that the oxidization of organic substance in the unpolluted soil was least. The organic carbon content reached the maximal $(0.98 \%)$ in the topsoil, and decreased with soil depth. It was undetected in the $51-80 \mathrm{~cm}$ horizon (Table 1).

The organic carbon contents in the polluted soil, compared with the control soil, increased sharply in the topsoil. The organic carbon content reached $5.87 \%$ in the P-2 polluted topsoil, which was higher than the other soil horizons (Table 2). The organic carbon content in the alluvial $0-4 \mathrm{~cm}$ horizon in the section of P-1 near the well was $4.68 \%$ and the buried 4-20 cm horizon was $1.18 \%$, whereas it was $0.56 \%$ in the 20-40 cm horizon. The organic carbon content in topsoil horizons of the polluted soils differed markedly from that in the correspondent horizons of the unpolluted soils (Table 1). However, it was no difference below the $20 \mathrm{~cm}$ horizons.

The speed of oxidization increased with increasing soil organic carbon content. In the polluted soils, insoluble organic carbon residuum accumulation was significant because of solidification. This is the beginning of the formation on the soil surface of solid salted crust. The salt content in the lower layer of solid saline soils was significant lower than that of topsoil. Total salt concentration in the surface layer was more than $1 \%$ (Table 2).

The thin soil crust was formed when the soil dried up. Eventually, all of clay and loam surfaces may be

Table 1 Organic carbon content and salt composition in the unpolluted grey-brown soils

\begin{tabular}{|c|c|c|c|c|c|c|c|c|c|c|c|}
\hline $\begin{array}{l}\text { No. of soil } \\
\text { section }\end{array}$ & $\begin{array}{l}\text { Depth } \\
(\mathrm{cm})\end{array}$ & $\mathrm{HCO}_{3}^{-}$ & $\mathrm{Cl}^{-}$ & $\mathrm{SO}_{4}{ }^{2-}$ & $\mathrm{Ca}^{2+}$ & $\mathrm{Mg}^{2+}$ & $\begin{array}{l}\mathrm{Na}^{+} \\
(\%)\end{array}$ & $\mathrm{K}^{+}$ & Total salt & $\mathrm{CO}_{2}$ & Organic carbon \\
\hline \multirow{5}{*}{$\begin{array}{l}\text { Unpolluted } \\
\text { grey-brown } \\
\text { soil }\end{array}$} & $0-3$ & 0.018 & 0.130 & 0.419 & 0.037 & 0.015 & 0.219 & 0.001 & 0.839 & 12.05 & 0.98 \\
\hline & $3-14$ & 0.015 & 0.241 & 0.483 & 0.051 & 0.020 & 0.277 & 0.001 & 1.193 & 12.35 & 0.88 \\
\hline & $14-35$ & 0.018 & 0.133 & 0.528 & 0.050 & 0.030 & 0.232 & 0.002 & 0.993 & 10.82 & 0.59 \\
\hline & $35-51$ & 0.015 & 0.208 & 0.541 & 0.060 & 0.021 & 0.290 & 0.002 & 1.137 & 10.21 & 0.42 \\
\hline & $51-80$ & 0.006 & 0.102 & 0.818 & 0.288 & 0.017 & 0.098 & 0.001 & 1.330 & 11.07 & - \\
\hline
\end{tabular}

Table 2 Organic carbon content and salt composition of oil-polluted saline soils

\begin{tabular}{|c|c|c|c|c|c|c|c|c|c|c|c|}
\hline $\begin{array}{l}\text { No. of soil } \\
\text { section }\end{array}$ & $\begin{array}{l}\text { Depth } \\
(\mathrm{cm})\end{array}$ & $\mathrm{HCO}_{3}^{-}$ & $\mathrm{Cl}^{-}$ & $\mathrm{SO}_{4}{ }^{2-}$ & $\mathrm{Ca}^{2+}$ & $\mathrm{Mg}^{2+}$ & $\begin{array}{l}\mathrm{Na}^{+} \\
(\%)\end{array}$ & $\mathrm{K}^{+}$ & Total salt & $\mathrm{CO}_{2}$ & Organic carbon \\
\hline \multirow{5}{*}{ P-1 } & $0-4$ & 0.019 & 1.088 & 0.954 & 0.326 & 0.097 & 0.605 & 0.010 & 3.097 & 13.92 & 4.68 \\
\hline & $4-20$ & 0.016 & 0.340 & 0.322 & 0.126 & 0.030 & 0.177 & 0.004 & 2.015 & 11.31 & 1.18 \\
\hline & $20-40$ & 0.007 & 0.058 & 0.712 & 0.261 & 0.018 & 0.041 & 0.002 & 2.104 & 12.37 & 0.56 \\
\hline & $40-120$ & 0.080 & 0.077 & 0.786 & 0.280 & 0.021 & 0.066 & 0.002 & 1.240 & 11.78 & - \\
\hline & $0-21$ & 0.019 & 0.098 & 0.529 & 0.182 & 0.021 & 0.072 & 0.005 & 0.921 & 9.07 & 5.87 \\
\hline \multirow[t]{2}{*}{$\mathrm{P}-2$} & $21-46$ & 0.012 & 0.044 & 0.672 & 0.233 & 0.018 & 0.051 & 0.003 & 1.033 & 10.58 & 0.65 \\
\hline & $46-75$ & 0.010 & 0.053 & 0.749 & 0.270 & 0.024 & 0.039 & 0.002 & 1.147 & 10.96 & 0.46 \\
\hline
\end{tabular}


covered by the crust. These processes were accompanied by desertification. Finally, in the region of accumulation, the soil surface would be transformed into solid saline soils.

\subsection{Organic carbon content changes with time in the oil-polluted soil}

Oil degradation was observed in polluted soil by oil stream 15 years ago. The bitumen substances were gradually transformed into insoluble chemicals and humic materials in the soils. This implies the change of organic carbon content in the soils with degradation of the bitumen substances. It showed that the multiple oil pollution of the soil could increase the organic carbon content continuously (Dusenov, 2001). The organic carbon content accumulated in the soil during the period of three years (Table 3 ). The organic carbon content decreased with increasing distance from the well. Compared with the unpolluted soil, the organic carbon content increased by $32.9 \%$ in the $0-10 \mathrm{~cm}$ topsoil horizon, which was $50 \mathrm{~m}$ away from the well. The organic carbon content in the 10-30 cm layer changed slightly. However, it decreased by $16.2 \%$ in the $30-50 \mathrm{~cm}$ layer (Table 3 ).

Table 3 Organic carbon content in the oil polluted soils at different times

\begin{tabular}{ccccc}
\hline & \multicolumn{4}{c}{ P-1N, polluted soil (\%) } \\
$\begin{array}{c}\text { Soil depth } \\
(\mathrm{cm})\end{array}$ & $\begin{array}{c}\text { P-control, } \\
\text { unpolluted } \\
\text { soil } \\
(\%)\end{array}$ & \multicolumn{3}{c}{ Age of pollution } \\
& 0.91 & \multicolumn{2}{c}{ The distance away from the well } \\
& $10 \mathrm{~m}$ & $50 \mathrm{~m}$ & $10 \mathrm{~m}$ \\
\hline $0-10$ & 0.75 & 0.85 & 0.80 & 1.80 \\
$10-30$ & 0.62 & 0.78 & 0.52 & 0.97 \\
$30-50$ & & & & 2.09 \\
\hline
\end{tabular}

The organic carbon content increased markedly in the 0-30 cm horizon in 15-year polluted soils but did not change significantly in the $30-50 \mathrm{~cm}$ horizon (Table 3). This result implied the bitumen substance in polluted soils was decomposed with time.

\subsection{Humus content and composition in the oil- polluted soil}

The composition of organic acids in the profile of grey-brown soils was shown in Table 4. The organic carbon content of the polluted soil and the amount of unhydrolyzed residual increased significantly compared with the unpolluted soil. The humic and fulvic acids and the ratio of humic acid to fulviv acid also changed (Table 4).

Increasing oxidation in the horizon of $0-10 \mathrm{~cm}$ could be attributed to the increase of fulvic acid in humus, which could be more easily oxidized than humic acid (Pikovsky, 1981). On the other hand, the higher oxidization of organic substance in the polluted topsoil could be related with higher molecular oxygen concentration. The oxidization of organic carbon decreased sharply in the $30-40 \mathrm{~cm}$ horizon due to the increase of humic acid content or the reduction conditions caused by insufficient molecular oxygen. In the $60-70 \mathrm{~cm}$ soil layer, oxidization of the organic carbon increased again because of more utilizable organic acids of low molecular weight dominated in this horizon (Table 4).

\section{Conclusion}

Chemical composition, properties, and structure of the soil were altered by crude oil pollution, with the humic horizon being most strongly affected. The content and mobility of humus components increased

Table 4 Group and fractional composition of organic substances in saline grey-brown loam soils

\begin{tabular}{|c|c|c|c|c|c|c|c|c|c|c|c|c|c|}
\hline \multirow{2}{*}{$\begin{array}{l}\text { No. of soil } \\
\text { section }\end{array}$} & \multirow{2}{*}{$\begin{array}{l}\text { Depth } \\
(\mathrm{cm})\end{array}$} & \multirow{2}{*}{$\begin{array}{l}\text { Organic } \\
\text { carbon } \\
\text { content in } \\
\text { soil }(\%)\end{array}$} & \multirow{2}{*}{$\begin{array}{l}\text { Unhydrolyzed } \\
\text { residual }(\%)\end{array}$} & \multirow{2}{*}{$\begin{array}{c}\text { Decalcine } \\
(\%)\end{array}$} & \multicolumn{4}{|c|}{ Humic acid (\%) } & \multicolumn{4}{|c|}{ Fulvic acid (\%) } & \multirow{2}{*}{$\begin{array}{l}\text { Humic acid } \\
\text { fulvic acid }\end{array}$} \\
\hline & & & & & I & II & III & Sum & I & II & III & Sum & \\
\hline \multirow{3}{*}{$\begin{array}{c}\text { P-6 } \\
\text { polluted } \\
\text { soil }\end{array}$} & $0-10$ & 6.48 & 30.69 & 5.57 & 0.34 & 10.65 & 26.29 & 37.28 & 14.63 & 7.25 & 4.57 & 26.45 & 1.40 \\
\hline & $30-40$ & 3.29 & 62.32 & 10.79 & 0.67 & 4.19 & 4.19 & 9.05 & 6.17 & 2.79 & 5.87 & 14.83 & 0.61 \\
\hline & $60-70$ & 4.65 & 84.64 & 5.82 & 0.24 & 2.97 & 2.06 & 5.27 & 0.97 & 8.84 & 2.99 & 4.26 & 1.23 \\
\hline \multirow{3}{*}{$\begin{array}{c}\mathrm{P}-7 \\
\text { unpolluted }\end{array}$} & $0-6$ & 0.78 & 14.74 & 3.46 & 1.41 & 13.2 & 22.05 & 36.66 & 29.61 & 8.84 & 6.67 & 45.12 & 1.35 \\
\hline & $6-13$ & 0.50 & 30.40 & 8.20 & 2.20 & 16.0 & 15.20 & 33.40 & 11.20 & 8.00 & 8.80 & 28.00 & 1.19 \\
\hline & $20-30$ & 0.57 & 15.96 & 9.65 & 5.96 & N/A & 10.88 & 16.84 & 4.91 & 24.21 & 28.42 & 57.45 & 0.29 \\
\hline
\end{tabular}


significantly in the soil due to long-term changes in oxidation-reduction conditions. Meanwhile, the continued oil-pollution led to the increase of organic carbon content in the soils.

\section{References}

Arinushkina E V. Manual of Chemical Analyses. Moscow: Issued of Moscow State University, 1961. 295.

Bigaliyev A B, Faizov K Sh, Asanbayev I K. The oil-pollutions of soils of Mangyshlak, Pre-Caspian Sea Regions. Herald of Kazakh State University, 2002, 2(11): 37-40.

Dusenov Z T. Oil-pollutions of soils of the Pre-Caspian Sea Region. Herald of Kazakh State University, 2001, 1(11): 37-40.

Khaziyev F K, Fatkhiyev F F. Change of biochemical processes in the soils under the oil-chemical pollutions and activation of oil destruction. Agro-chemistry, 1981, 1: 102-111.

Khaziyev F K, Khasanov I Y, Shamsutdinov B U. Influencing of oil-pollutions to soil. Problems of Complex Studying, Development and Protection of Environment of Ural Region. Ufa: Thesis Reports, 1980. 14-16.

Khaziyev F K. System-ecological Analyses of Ferment Activity of Soil. Moscow: Science, 1982. 203.

Pikovsky Yu I. Geochemical properties of technological streams in

\section{Acknowledgements}

The research was supported by Government Order of the Ministry of Education and Science of the Republic of Kazakhstan (0106 RK).

the oil-field regions. Technological Streams of Substance in the Landscapes and Ecosystem Condition. Moscow: Science, 1981. $134-148$.

Pikovsky Y I. Natural and Technological Hydrocarbon Streams in the Environment. Moscow State University, 1993. 204.

Ponomoreva V V, Plotnikova T A. Methods of definition of group and fractional composition of humus. Agrochemical Methods of Soil Studying. Moscow: Science, 1975. 47-56.

Samosova S M, Gubaidullina T S, Filchenkova V I, et al. Influencing of oil-pollution to the soil biological activity. Problems of Development of Automatic System of Control Surveillance and Evaluation of Environment Condition. Kazan: All-union Science-technical Conference, 1979. 138-139.

Saparov A S, Faizov K S, Asanbayev I K. Soil-ecological Condition of the Pre-Caspian Sea Oil Regions and the Way of its Improving. Almaty, 2006. 146.

Turin I V. Organic Substances of Soils. Moscow, 1937. 285. 